\title{
Research Note: Effects of leaf decomposition of selected exotic and native tree species on forest soil quality
}

\author{
Cheryl C. Batistel ${ }^{1,2}$ and Victor B. Asio ${ }^{1}$ \\ ${ }^{1}$ Institute of Tropical Ecology, Visayas State University, Baybay City, Leyte 6521-A, \\ Philippines; ${ }^{2}$ Institute of Agroecology and Plant Production in the Tropics and \\ Subtropics University of Hohenheim, 70599 Stuttgart, Germany
}

\begin{abstract}
The study evaluated the effects of incorporation and subsequent decomposition of leaves of exotic tree species (Gmelina arborea, Swietenia macrophylla and Tectona grandis) and native tree species (Pterocarpus indicus, Dipterocarpus validus and Parashorea plicata) on the quality of forest soil. Forty-two pots containing an acidic and clayey forest soil and added with fresh leaves of the different tree species were setup in an open area in Mt. Pangasugan. Retrieval of the first three pots for each treatment was done after two months and the remaining three pots, five months later. Soil samples were collected from each pot and were analyzed for soil respiration rate, $\mathrm{pH}, \mathrm{OM}$, total $\mathrm{N}$ and available $\mathrm{P}$. Findings showed that in general the exotic tree species did not change the soil $\mathrm{pH}$ while the native species appeared to decrease it. Regardless of tree species, leaf decomposition significantly increased available soil phosphorus. The leaves of the exotic tree species decomposed faster than those of the native tree species.
\end{abstract}

Keywords: leaf decomposition, exotic and native tree species, soil respiration rate, forest soil quality

Correspondence: C.C. Batistel. Institute of Agroecology and Plant Production in the Tropics and Subtropics. University of Hohenheim.70599 Stuttgart, Germany.E-mail: c_batistel@yahoo.com DOI: 10.32945/atr3013.2008 
Batistel and Asio

\section{INTRODUCTION}

Decomposition of organic materials on the forest floor is a vital link between the various components of the forest ecosystem. Through this process, mineral nutrients contained in the biomass are released into the soil which are then subject to reabsorption by plants, fixation by soil components, losses by leaching and runoff. Decomposition can have considerable influence on the biological and chemical properties of the forest soil depending on the chemistry of the organic material. The process is generally affected by the kind of organic material, soil and climatic factors, and the availability of decomposers (e.g. Gartner and Cardon, 2004).

Exotic tree species are introduced species from other regions. They are widespread in tropical and subtropical countries since they are popular as reforestation species even in harsh environments (Nyland, 1996) due to their ability to adapt easily to variable site conditions (Weidelt, 1976). They are considered economically viable because of their fast growth characteristic. Farmers value exotic species more than the native ones because of forestry extension recommendations and desirable cultural attributes (Cromwell and Bradie, 1996). In the Philippines, the most well-known tree species belonging to this group are mahogany (Swietenia macrophylla King, gmelina (Gmelina arborea Roxb.) and teak (Tectona grandis Linn.).

Native tree species are species which originate from the place where they are growing. Among the more commonly known Philippine native tree species are bagtikan (Parashorea plicata Brandis), hagakhak (Dipterocarpus validus Blume) and narra (Pterocarpus indicus Willd.). These species belong to family Dipterocarpaceae.

Presently, there is widespread notion that the use of exotic tree species as reforestation species causes negative ecological effects such as soil degradation (Sawyer, 1993). Lindsay and French (2005) cited early studies showing that there are strong positive feedbacks between plant species composition and soil properties such that introduction of a new species can change nutrient cycling and soil properties. In contrast, it is also believed that native tree species have positive effects on the site. However, very little data exist to support these claims. Thus, this study aimed to verify the hypothesis that decomposition of the leaves of exotic and native tree species has different effects on the quality of forest soil. 


\section{MATERIALS AND METHODS}

Bulk soil material for use as potting medium was collected from the B horizon of the typical forest soil in Mt. Pangasugan having low organic matter content and less affected by the litter of the standing vegetation. The collected soil was air-dried, thoroughly mixed, and allowed to pass a $4 \mathrm{~mm}$ wire mesh sieve. Then, $1 \mathrm{~kg}$ soil was weighed and placed in each of the 42 polyethylene bags with a dimension of $10 \times 10 \times 27 \mathrm{~cm}$ with a thickness of $0.25 \mathrm{~mm}$. Another bag of soil was kept which served as the initial forest soil sample.

Healthy mature leaves were collected from six trees of each selected exotic and native tree species growing in the area surrounding the site where the bulk soil material was collected. The exotic species sampled included Swietenia macrophylla, Gmelina arborea and Tectona grandis while the native species were Parashorea plicata, Dipterocarpus validus and Pterocarpus indicus. The leaf samples were then cut into small pieces using a pair of scissors then fifty grams $(50 \mathrm{~g})$ of leaf sample per tree species was mixed with the soil.

The experiment was set-up in an open area in the seedling nursery of the Institute of Tropical Ecology in Mt. Pangasugan and was arranged following the Completely Randomized Design (CRD) with the different tree species as treatments. Six bags represented each tree species and a control treatment (no leaf incorporation) for a total of 42 bags. Initial soil analysis was done on the soil samples. After two months, the first three bags for each tree species were collected for soil analysis. The remaining three bags per species were retrieved three months later ( 5 months from the start of the experiment) also for soil analysis.

Soil $\mathrm{pH}$ was determined potentiometrically using a soil: water ratio of 1:2.5 (ISRIC, 1995). Soil organic matter was analyzed following the Walkley and Black wet combustion method (ISRIC, 1995). Total nitrogen content of both soil and tissue samples were determined by Kjeldahl method (Jackson, 1958). Available phosphorus content of soil was analyzed following the Bray No.2 method (ISRIC, 1995) while the total P content of the leaf samples was analyzed by first dry ashing the sample at $500^{\circ} \mathrm{C}$ for a minimum of 5 hours (but not exceeding 16 hours) followed by the addition of $6 \mathrm{M}$ hydrochloric acid. Quantification of P was done using a spectrometer (Westerman, 1990). Respiration rate was determined by incubation in airtight glass jars $(500 \mathrm{ml}$ volume) and simple titrimetric method for measuring $\mathrm{CO}_{2}$ evolution from soils. 
Differences in soil quality as affected by the decomposition of leaves of exotic and indigenous tree species were evaluated by computing the analysis of variance (ANOVA) following Completely Randomized Design.

\section{RESULTS AND DISCUSSION}

\section{Characteristics of soil and leaves used}

The soil used as potting medium was taken from the B horizon of a highly weathered forest soil developed from basaltic and andesitic volcanic rocks in Mt. Pangasugan classified as an Ultisol (Tropudult). The soil was clayey $(60 \%$ clay), yellowish red in color with kaolonitic and halloysitic clay mineralogy (Jahn and Asio, 1998). Initial chemical analysis showed that the soil had a pH in $\mathrm{H} 2 \mathrm{O}$ of 5.35 , organic matter content of $1.56 \%$, total $\mathrm{N}$ content of $0.099 \%$ and a trace amount of available $P$.

Leaves of exotic species used in the study were generally thinner compared to those of the native species. G. arborea and T. grandis had the thinnest leaves while $D$. validus had the thickest leaves although they were only slightly thicker than those of P. plicata, S. macrophylla and P. indicus.

Table 1 shows the nitrogen and phosphorus concentrations in the leaves of the different species studied. P. indicus, a leguminous species, and $G$. arborea had the highest $\mathrm{N}$ leaf contents. $T$. grandis had the lowest while $P$. indicus had the highest $\mathrm{P}$ contents. It also shows that $\mathrm{T}$. grandis which had the lowest amount of $\mathrm{P}$ also had the lowest $\mathrm{N}$ content.

The tissues of most green plants are composed of carbohydrates, fats, oils, waxes, lignins and proteins, which are made up of carbon, hydrogen, and oxygen. The carbohydrates and proteins are easily decomposed into phosphates, sulfates, nitrates, ammonia, carbon dioxide, water and several products of calcium. These substances generally cause changes in the $\mathrm{pH}$ and other characteristics of the soil (e.g. Tate, 2000; Schachtschabel et al., 1992). 
Table 1. Nitrogen and phosphorus concentrations in leaf samples of selected exotic and native tree species

\begin{tabular}{lll}
\hline Treatments & Total N (\%) & Total P $(\%)$ \\
\hline Gmelina arborea & 2.324 & 0.182 \\
Swietenia macrophylla & 1.977 & 0.155 \\
Tectona grandis & 0.324 & 0.077 \\
Pterocarpus indicus & 2.219 & 0.186 \\
Dipterocarpus validus & 1.729 & 0.082 \\
Parashorea plicata & 1.730 & 0.079 \\
\hline
\end{tabular}

Effects of leaf decomposition on soil quality

Soil pH

To evaluate the changes in soil $\mathrm{pH}$ as a result of leaf decomposition, fresh and air-dry soil samples retrieved from each pot were analyzed. The $\mathrm{pH}$ of fresh soil samples generally gives information on the actual $\mathrm{pH}$ of the soil (or field $\mathrm{pH}$ ). On the other hand, the $\mathrm{pH}$ of air-dry soil samples may not reflect the actual soil reaction due to possible chemical changes in the soil as a result of drying although it is the standard method for soil $\mathrm{pH}$ determination.

Results revealed highly significant effects of leaf incorporation and decomposition on the $\mathrm{pH}$ of fresh soil sample (Table 2). There was an observable difference between the effects of the exotic species and the native species on soil $\mathrm{pH}$. Among the 3 exotic species, only T. grandis caused a significant decrease in fresh soil $\mathrm{pH}$ after 2 months but the effect became nonsignificant after 5 months. $S$. macrophylla even significantly increased soil pH after 5 months. In contrast, all 3 native species decreased soil $\mathrm{pH}$ after 2 months although the change due to $P$. plicata was not statistically significant relative to the control. The effects of the different tree species may be due to differences in leaf chemistry.

Barekzai and Mengel (1993) hypothesized that decomposition of organic materials low in organic nitrogen leads to an increase in soil $\mathrm{pH}$. Findings of this present study do not support the said hypothesis since $S$. macrophylla, which resulted in the highest soil $\mathrm{pH}$, had moderate $\mathrm{N}$ content. On the other hand, $T$. grandis resulted in the lowest $\mathrm{pH}$ even though it had the lowest $\mathrm{N}$ content. 
34

Batistel and Asio

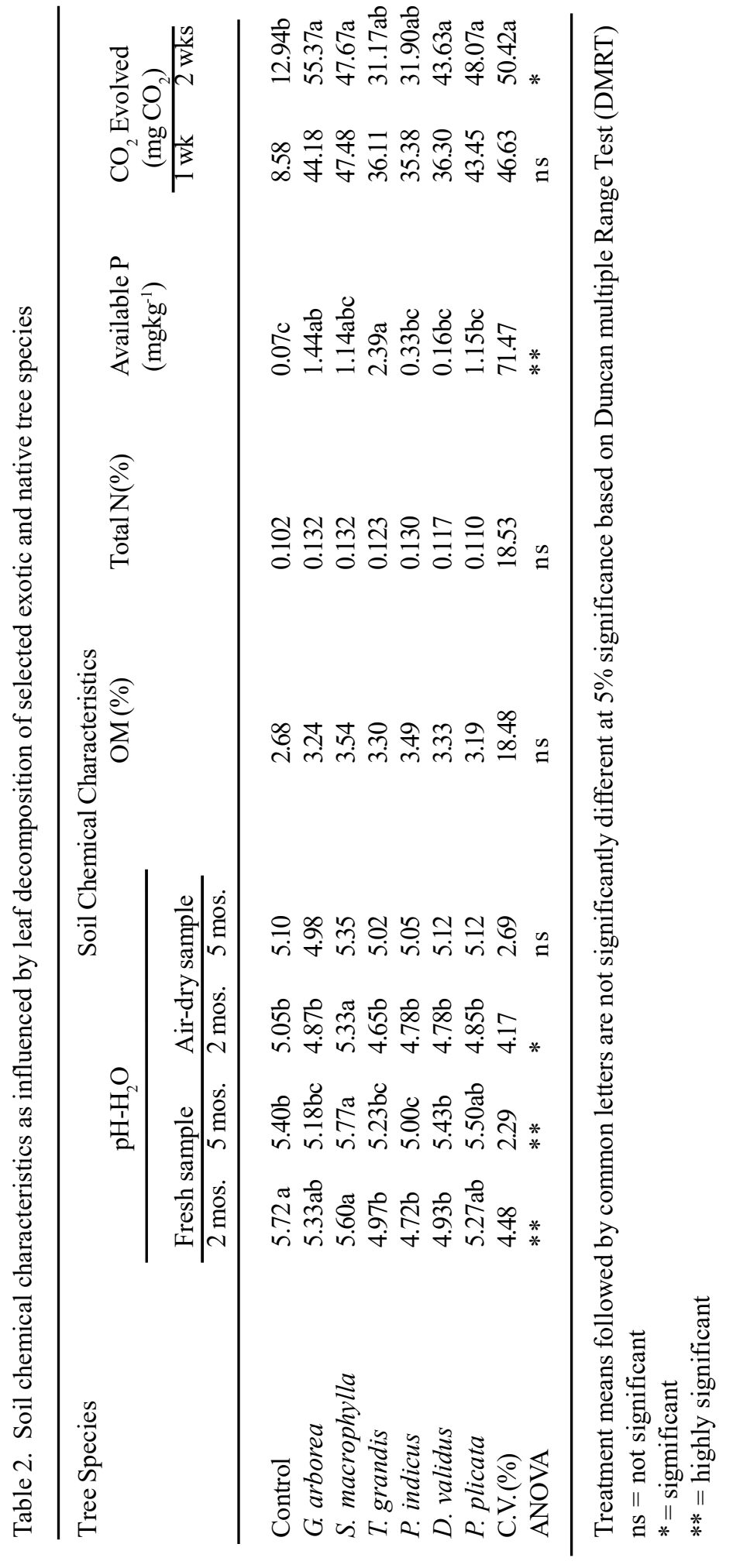


Table 3. Amount of undecomposed leaf material of selected exotic and native species two and five months from soil incorporation.

\begin{tabular}{lcc}
\hline \multirow{2}{*}{ Species } & \multicolumn{2}{c}{ Weight of Undecomposed Leaf Material (g) } \\
\cline { 2 - 3 } & After 2 months & After 5 months \\
\hline Gmelina arborea & 0.01 & 0 \\
Swietenia macrophylla & 0.75 & 0 \\
Tectona grandis & 0.11 & 0 \\
Pterocarpus indicus & 0.76 & 0 \\
Dipterocarpus validus & 1.94 & 0.27 \\
Parashorea plicata & 1.23 & 0.11 \\
\hline
\end{tabular}

The increase in $\mathrm{pH}$ of the soil applied with leaves of S. macrophylla may be ascribed to its high calcium content of $40 \mathrm{~g} / \mathrm{kg}$ (unpublished data of Prof. R. Jahn of the University of Halle-Wittenberg). Schachtschabel et al. (1992) mentioned that calcium is one of the basic cations in the soil responsible for high soil $\mathrm{pH}$ values.

\section{Soil organic matter}

Results revealed no significant differences in the OM contents of the soil applied with leaves of various exotic and native species (Table 2). However, there was a general tendency for the treated soil to have higher OM contents than the control.

Soil OM includes everything from the newly added materials to the thoroughly decomposed polymerized residual matter known as humus. Soil OM content generally depends on the addition of plant materials by vegetation cover minus the losses due to decomposition. The lowest OM content of the control pots can be expected since no organic material was added to them.

The above findings suggest that trees, regardless of species, can improve the organic matter of the soil. Mora (2004) observed an increase in the OM content of soils under various exotic, native and fruit trees.

Table 3 shows the amount of undecomposed leafmaterial retrieved from the treatment pots two and five months from the start of the experiment. As can be observed, the leaves of the exotic species generally decomposed faster than those of the native species. Only D. validus and P. plicata had some undecomposed leaf material that remained five months from the start of the experiment. This faster rate of leaf decomposition of exotic species could be 
Table 4. Average soil temperature in the pots incorporated with leaves of exotic and native tree species

\begin{tabular}{lcc}
\hline \multirow{2}{*}{ Treatments } & \multicolumn{2}{c}{ Soil Temperature $\left({ }^{\circ} \mathrm{C}\right)$} \\
\cline { 2 - 3 } & After 2 months & After 5 months \\
\hline \multirow{2}{*}{ Control (without leaves) } & 30.00 & 25.00 \\
Gmelina arborea & 31.33 & 25.07 \\
Swietenia macrophylla & 31.33 & 24.93 \\
Tectona grandis & 30.67 & 25.03 \\
Pterocarpus indicus & 30.83 & 24.97 \\
Dipterocarpus validus & 31.83 & 24.97 \\
Parashorea plicata & 30.17 & 25.00 \\
& & \\
\hline
\end{tabular}

attributed to their generally thinner leaves compared to those of the native species. Moreover, the leaves of the exotic species were less shiny suggesting a thinner cuticle and less deposition of wax. It is also possible that they contain other substances such as lignin and soluble polyphenols that could slow down the decomposition process. This finding seems to agree with the report of Rothstein et al. (2004) based on their study in a Hawaiian mountain forest.

Data on soil temperature of the pots showed non-significant differences among treatments (Table 4). This indicates that the type of organic material had no effect on soil temperature. Likewise, it implies that the soil temperature cannot be a reason for the faster decomposition of leaves of the exotic species.

It was also observed that the soil temperature in the pots was much higher after two months. This can be ascribed to the heat produced during the rapid decomposition of the leaf material after two months.

\section{Available phosphorus}

Table 2 shows the highly significant differences in soil available $\mathrm{P}$ as influenced by decomposition of leaf material of various tree species. Available $P$ of the soil incorporated with leaves of exotic species ranged from 1.14 to $2.39 \mathrm{mgkg}^{-1}$ while for the native species, it ranged from 0.16 to $1.15 \mathrm{mgkg}^{-1}$. Although not statistically different, there was a general tendency for the exotic species to contribute to higher available $P$ in the soil. However, all values were much below the sufficient level of $10-15 \mathrm{mgkg}^{-1}$ for most crops (Landon, 
1991) although wild plants are known to require much lower amounts of nutrients than cultivated plants (Chapin, 1980). Based on the above findings, it maybe speculated that on the long-term, all the tree species studied could improve the P status of the forest soil. Susaya and Asio (2005) found that much of the $\mathrm{P}$ in the rainforest of Mt. Pangasugan is fixed in the forest biomass. This suggests that prolonged addition of litter would increase the P status of the soil.

\section{Total nitrogen}

Results revealed no significant changes in the total $\mathrm{N}$ content of the soil after the incorporation of the leaves of various tree species (Table 2). Moreover, all values were lower than the sufficient value in the soil of $0.2 \%$ (Landon, 1991). The main sources of soil organic $\mathrm{N}$ are symbiotic and non-symbiotic fixation, rain and dusts (Sanchez, 1976). In the forest tree plantations, different results could be expected since leguminous tree species like $P$. indicus may contribute significant amounts of nitrogen to the soil through biological nitrogen fixation in their roots. In contrasts, the present study focused only on the short-term impact of leaf decomposition on the soil.

\section{Respiration rate}

Soil respiration is usually measured based on the amount of $\mathrm{CO}_{2}$ evolved by the soil. Schachtschabel et al. (1992) reported that two-thirds of $\mathrm{CO}_{2}$ by the soil is the product of aerobic respiration through OM decomposition by microorganisms and the other one-third is produced by the roots and soil animal respiration. In this study, no roots and soil animals were present in the soil since this was a pot experiment. Thus, almost all of the $\mathrm{CO}_{2}$ released by the soil could be due to the microbial decomposition of the added organic material. Results revealed that incorporation of the leaves of the tree species enhanced high soil respiration compared to the control. However, no significant differences were found among the different species after one week of incubation (Table 2). Extending the incubation period to two weeks resulted in significant differences between the leaf-treated soils and the control. G. arborea showed the highest rate of soil respiration although it was not significantly different from the other species. This result generally agrees with that of the litter decomposition study by litterbag method conducted in the site by Aragon (2004). 
The data also indicate that the greatest production of $\mathrm{CO}_{2}$ occurred during the first week of incubation. This could be due to the possibility of a negative feedback caused by the increased $\mathrm{CO}_{2}$ concentrations inside the jars which could have inhibited soil microbial activity.

\section{CONCLUSIONS}

Based on the results of the study, it can be concluded that:

1. Decomposition of the leaves of exotic tree species generally did not change fresh soil $\mathrm{pH}$ except that of $S$. macrophylla which increased soil $\mathrm{pH}$ after 5 months. In contrast, the leaves of the native species tended to decrease fresh soil $\mathrm{pH}$ particularly in the first two months of decomposition.

2. There was no considerable difference between the effects of the leaves of exotic and those of native tree species on the organic matter and total nitrogen contents of the soil.

3. Available phosphorus content of the soil was significantly increased by the decomposition of leaves of both exotic and native species.

4. The leaves of exotic tree species tended to decompose faster than those of the native species.

\section{LITERATURE CITED}

ARAGON, J. A. 2004. Leaf litter decomposition of Dipterocarpus validus Brandis (Dipterocarpaceae) and Gmelina arborea (Verbenaceae) in two forest sites of Mt. Pangasugan. Undergrad Thesis, Leyte State University, Baybay, Leyte. 50 pp.

BAREKZAI, A. and K. MENGEL. 1993. Effect of microbial decomposition of mature leaves on soil pH. Z. Pflanzenernahr. Bodenk 156:93-94.

CHAPIN, FS III. 1980. The mineral nutrition of wild plants. Annual Review of Ecology and Systematics 11: 233-260.

CROMWELL, E. and A. BRADIE. 1996. Germplasm for Multipurpose Trees: Access and Utility in Small-farm Communities. ODI London. 
GARTNER, T.B. and Z.G. CARDON. 2004. Decomposition dynamics in mixed species leaf litter. Oikos 104: 230-246.

INTERNATIONAL SOIL REFERENCE AND INFORMATION CENTER (ISRIC). 1995. Procedure for Soil Analysis. Wageningen.

JACKSON, M.L. 1958. Soil Chemical Analysis. Prentice Hall Inc., New Jersey.

JAHN, R and V.B. ASIO. 1998. Soils of the tropical forest of Leyte, Philippines. I.Weathering, characteristics, classification and site qualities. In: Schulte $A$ and Ruhiyat D, editors. Soils of Tropical Forest Ecosystems. Springer Verlag, Berlin, pp. 29-36.

LANDON, J. R. 1991. Booker Tropical Soil Manual. Longman Scientific and Technical, Essex England.

LINDSAY, E.A. and K. FRENCH. 2005. Litterfall and nitrogen cycling following invasion by Chrysanthemoides monilifera ssp. Rotundata in coastal Australia. Journal of Applied Ecology 42: 556-566.

MORA, C.G. 2004. Mineral nutrient status of selected forest and fruit tree species in an agroforestry system in Baybay, Leyte. Undergrad. Thesis, Leyte State University, Baybay, Leyte, 50pp.

NYLAND, R. 1996. Silviculture (Concepts and Application). McGraw-Hill Co. Inc. Singapore.

ROTHSTEIN, D.E., P.M. VITOUSEK and B.L. SIMMONS. 2004. An exotic tree alters decomposition and nutrient cycling in a Hawaiian montane forest. Ecosystems 7: 805-814.

SANCHEZ, P. A. 1976. Properties and Management of Soils in the Tropics. John Wiley and Sons. Raleigh, North Carolina.

SAWYER, J. 1993. Plantations in the Tropics: Environmental Concerns. IUCN/UNEP/ WWWF, Gland, Switzerland.

SCHACHTSCHABEL, P., H. P. BLUME, G. BRUMMER, K. H. HARTGE and U. SCHWERTMANN. 1992. Textbook of Soil Science (13th). Enke Verlag, Stuutgart. (in German).

SUSAYA, J.P. and V.B. ASIO. 2005. Status and distribution of phosphorus in the rain forest of Mt. Pangasugan, Leyte, Philippines. Annals of Tropical Research 27: 815

TATE, R.L. 2000. Soil Microbiology. Wiley, John and Sons, New York.

WEIDELT, H. A. 1976. Manual of Reforestation and Erosion Control for the Philippines. German Agency for Technical Corporation LTD (GTZ) Germany. 